Jurnal Ilmu Ilmu Agribisnis: Journal of Agribusiness Science, 9(4), November 2021

\title{
NILAI TAMBAH DAN HARGA POKOK PRODUKSI SOSIS GULUNG DI CV CUCURUTUKU CERIA BANDAR LAMPUNG
}

\author{
(Added Value and The production costs sausage rolls in CV Cucurutuku Ceria Bandar Lampung)
}

Nidya Oktaviani, Wuryaningsih Dwi Sayekti, Indah Listiana

Jurusan Agribisnis, Fakultas Pertanian, Universitas Lampung, Jl. Prof. Dr. Soemantri Brojonegoro No. 1 Bandar Lampung 35141, e-mail : wuryaningsih.dwisayekti@fp.unila.ac.id

\begin{abstract}
This research aims to analyze the added value, the amount of production cost and selling cost of sausage rolls. The method used in this research is case study. The location is chosen purposively at CV Cucurutuku Ceria in Bandar Lampung with consideration that CV Cucurutuku Ceria trading business is one of the highest producers of sausage rolls in Bandar Lampung. The data of this research are primary data and secondary data, collected in March-April 2019. The first objective is analyzed by using the Hayami method, the second objective is analyzed using the Variable Costing method, and the third objective was analyzed by adding the total non-production cost and the cost of production per month. The results of the research showed that the highest added value was come from the cheesy sausage rolls while the lowest was from potato sausage rolls. All variants have positive added values and were feasible to be produced. The average cost of a noodle sausage roll production $R p 962.85$, a soya sausage roll Rp1,926.86, a cheesy sausage roll $R p 1,768.44$, a potato sausage roll $R p 2,182.56$ and a spicy sausage roll Rp1,982.22. The selling price of a noodle sausage roll Rp1,439.95, a soya sausage roll Rp5,180.52, a cheesy sausage roll Rp4,216.63, a potato sausage roll Rp6,907.81 and a spicy sausage roll Rp4,447.20.
\end{abstract}

Key word: added value, cost of production and sausage rolls.

\section{PENDAHULUAN}

Peternakan merupakan salah satu penopang bagi kesejahteraan masyarakat yang termasuk dalam bidang pertanian. Bidang peternakan sangat potensial dan berpengaruh tidak hanya dalam kesejahteraan masyarakat umum saja akan tetapi sangat berpengaruh juga terhadap pendapatan suatu daerah, baik lokal maupun nasional. Bidang peternakan memiliki potensi bisnis yang sangat besar dan mempengaruhi hajat hidup orang banyak yang terlibat di dalam bidang tersebut, salah satu cabangnya yaitu unggas (ayam).

Daging ayam merupakan bahan makanan bergizi tinggi yang mudah untuk didapat, sering dikonsumsi, rasanya enak, teksturnya empuk, serta harga yang terjangkau sehingga disukai banyak orang. Daging ayam yang biasa dikonsumsi di Indonesia salah satunya adalah daging ayam ras pedaging (broiler) (Windiani dan Ari 2014). Harga daging ayam yang cukup terjangkau dan rasanya yang enak membuat daging ayam cukup banyak dipilih masyarakat, daging ayam ras pedaging dapat dijadikan suatu usaha mulai dari skala usaha rumah tangga hingga skala usaha besar yang dapat ditemukan di seluruh provinsi di Indonesia salah satunya adalah di Provinsi Lampung.

Menurut Dinas Perkebunan dan Peternakan Provinsi Lampung (2018), jumlah produksi daging ayam ras pedaging di Provinsi Lampung tahun 2017 sebesar 39.772.201 kg, produksi tersebut mengalami peningkatan sebesar 5,31 persen dari tahun 2015-2017. Peningkatan tersebut diikuti juga dengan meningkatnya jumlah konsumsi daging ayam ras pedaging pada tahun 2017 sebesar 0,29 kg per kapita, dengan peningkatan sebesar 12,68 persen dari tahun 2015-2017. Jumlah konsumsi daging ayam ras pedaging per kapita sebulan yang meningkat dari tahun ke tahun menjadi daya tarik industri daging ayam tersebut salah satunya sosis ayam. Sosis ayam mengalami inovasi menjadi olahan lanjut dari sosis salah satunya sosis gulung.

Sosis gulung merupakan inovasi dari sosis yang dibalut dengan bahan makanan lain yaitu mie, kentang, keju, soya dan mie pedas. Perusahaan yang mengolah sosis menjadi sosis gulung di Bandar Lampung salah satunya CV Cucurutuku Ceria. CV CC terletak di Jalan Griya Utama Way Halim Permai no II/C/4 Bandar Lampung. 
Tabel 2. Harga pokok produksi menggunakan metode variable costing

\begin{tabular}{lcc}
\hline Keterangan & \multicolumn{2}{c}{ Nilai } \\
\hline Jumlah produksi per bulan & \multicolumn{2}{c}{ (A) } \\
Biaya bahan baku langsung per bulan & (B) & \\
Biaya tenaga kerja langsung per bulan & (C) & \\
Biaya overhead variabel & (D) & \\
Total harga pokok produksi (B+C+D) & & (E) \\
Harga pokok produksi per buah (E/A) & & (F) \\
\hline
\end{tabular}

proses pemasaran. Perhitungan harga pokok produksi menggunakan metode variable costing yang dapat dilihat pada Tabel 2. Metode tersebut juga digunakan oleh penelitian Laisa, Sayekti dan Nugraha (2013) menggunakan variable costing.

Metode variable costing merupakan metode penentuan harga pokok produksi yang hanya memperhitungkan biaya produksi (biaya bahan baku, biaya tenaga kerja langsung. Menurut Mulyadi (2005) harga pokok penjualan adalah total biaya yang dibagi dengan jumlah produksi. Harga pokok penjualan dalam penelitian dihitung berdasarkan hasil penjumlahan antara harga pokok produksi dengan biaya nonproduksi.

Biaya nonproduksi terdiri dari biaya pemasaran yang meliputi biaya iklan, biaya sablon kemasan, biaya sertifikasi MUI, biaya freezer outlet dan biaya bensin. Penentuan harga pokok produksi dihitung menggunakan rumus menurut Mulyadi (2002) yang hanya memperhitungkan biaya produksi (biaya bahan baku, biaya tenaga kerja langsung, dan biaya overhead pabrik). yang dapat dilihat pada Tabel 2.

\section{HASIL DAN PEMBAHASAN}

\section{Profil Usaha}

Usaha Sosis Gulung CV CC berdiri pada tanggal 7 Juli tahun 2012. Saat itu usaha ini hanya bermodal sebesar Rp300.000,00 yang berasal dari uang pribadi. Usaha ini memiliki 23 tenaga kerja yang terdiri dari 10 tenaga kerja bagian produksi, delapan tenaga kerja bagian penjaga outlet dan lima tenaga kerja bagian kantor. Usaha ini melakukan kegiatan produksi dalam satu bulan sebesar 26 kali produksi. Hingga saat ini produksi terus mengalami peningkatan dengan jumlah produksi pada tahun 2019 sebesar 64.377 buah dari semua varian. Harga beli sosis ayam sebesar Rp750,00 per buah atau Rp30.000,00 per kg yang dibeli dari PT Ciomas.
Permintaan konsumen yang semakin tinggi maka pemilik membuka outlet lainnnya untuk menjangkau lebih banyak konsumen. Hingga saat ini CV CC sudah memiliki 16 outlet yang tersebar di Kota Bandar Lampung, Kota Metro dan Kota Malang. Kini usaha ini memiliki lima varian sosis gulung yaitu noodle sosgul, soya sosgul, potato sosgul, cheesy sosgul dan spicy sosgul yang dapat ditemukan di beberapa outlet. Namun pada penelitian ini hanya meneliti di daerah Bandar Lampung saja dikarenakan agar lebih mudah dijangkau.

\section{Proses Produksi}

Sosis gulung di CV CC memiliki lima varian yakni noodle sosgul, soya sosgul, potato sosgul, cheesy sosgul dan spicy sosgul, masing-masing varian melewati proses produksi yang berbeda-beda. Proses pengolahan noodle sosgul dan cheesy sosgul hanya dibalut oleh mie dan keju saja, sedangkan varian soya sosgul, potato sosgul dan spicy sosgul dengan menambahkan adonan tambahan (dada ayam) yang dibalurkan pada sosis, setelah dilakukan proses produksi semua varian sosgul langsung dikirim ke outlet-outlet dan disimpan langsung kedalam freezer yang tersedia dimasing-masing outlet yang tersebar di daerah Bandar Lampung dan Metro.

\section{Penggunaan Sarana Produksi}

Bahan baku merupakan faktor penting dalam menentukan tingkat harga pokok dan kelancaran proses produksi dalam usaha. Sosis ayam merupakan bahan baku yang digunakan untuk pembuatan sosis gulung. Harga beli sosis ayam sebesar Rp750,00 per buah atau Rp30.000,00 per $\mathrm{kg}$ yang dibeli dari PT Ciomas. Total jumlah bahan baku yang digunakan dalam sebulan sebesar 64.377 buah dari masing-masing varian sosis gulung.

Biaya tenaga kerja dalam penelitian ini adalah tenaga kerja yang berasal dari luar keluarga dan terlibat langsung dalam proses produksi yang terdiri dari tenaga kerja produksi dan tenaga kerja penjaga outlet. Rata - rata biaya tenaga kerja per orang pada bagian produksi sebesar Rp1.200.000,00 per bulan sedangkan rata- rata biaya tenaga kerja penjaga outlet per orang sebesar Rp1.000.000,00 per bulan. Selain bahan baku, usaha ini juga menggunakan bahan penunjang dalam memproduksi sosis gulung antara lain dada ayam, mie, keju, soya, kentang , tepung tapioka, tepung terigu, susu, mentega, minyak goreng gula, 
lada hitam, lada putih, bawang putih, bawang bombay, cabai merah, kentang, dan rempahrempah lainnya sedangkan bahan penolong yang digunakan dalam memproduksi sosis gulung antara lain tusukan bambu dan gas $12 \mathrm{~kg}$.

Total biaya bahan penunjang yang dikeluarkan oleh usaha sosis gulung CV CC sebesar Rp17.246.790,00 per bulan. Biaya overhead pabrik (BOP) variabel terdiri dari biaya bahan penunjang, biaya listrik, dan biaya kemasan. Jumlah produksi merupakan total jumlah sosis gulung yang dihasilkan dalam waktu sebulan. Biaya bensin merupakan biaya yang dikeluarkan untuk bahan bakar kendaraan dalam mengirim produk sosgul ke outlet-outlet. Total biaya bensin yang dikeluarkan oleh CV CC sebesar Rp1.400.000,00 per bulan.

\section{Analisis Nilai Tambah}

Berdasarkan prosedur perhitungan metode nilai tambah Hayami, perhitungan nilai tambah dapat dilihat pada Tabel 3 diperoleh nilai konversi pada masing-masing varian sebesar satu. Nilai konversi tersebut menyatakan bahwa setiap satu buah sosis ayam yang dikeluarkan oleh CV CC menghasilkan satu buah noodle sosgul, soya sosgul, potato sosgul, cheesy sosgul dan spicy sosgul. Nilai konversi dari semua varian sebesar satu dikarenakan bahan baku yang digunakan dilihat bukan berdasarkan berat produk tapi berdasarkan satuan produk, bahan baku yang digunakan yaitu sosis ayam, jika sebelum diolah ataupun sudah diolah tetap berupa satu buah sosis ayam. Penelitian ini berbeda dengan penelitian Febriyanti, Affandi dan Kalsum (2017) yang menunjukkan bahwa nilai konversi yang dihitung berdasarkan berat produk kilogram bukan berdasarkan satuan buah

Total hari kerja untuk memproduksi sosis gulung dihitung per satu bulan produksi. Jumlah total hari kerja usaha ini sebesar $26 \mathrm{HOK}$ per bulan. Upah tenaga kerja didasarkan upah harian rata-rata yang diterima masing-masing tenaga kerja produksi sosis gulung. Upah rata-rata yang diterima tenaga kerja produksi per hari sebesar Rp46.153,85 per orang dengan masing-masing varian terdiri dari dua orang tenaga kerja.

Semua varian sosis gulung pada CV Cucurutuku Ceria memberikan nilai tambah yang positif, sehingga penelitian ini sejalan dengan penelitian Ayu, Ismono dan Soelaiman (2013) dengan judul analisis nilai tambah pada klaster industri pengolahan ikan teri menunjukkan bahwa usaha itu memberikan nilai tambah lebih besar daripada nol $\mathrm{NT}>0$ ). Nilai tambah yang dihasilkan oleh masingmasing produk atau varian pada usaha sosis gulung $\mathrm{CV} \quad \mathrm{CC}$ bernilai (positif).

Tabel 3. Nilai tambah produk olahan sosis gulung CV Cucurutuku Ceria Bandar Lampung

\begin{tabular}{|c|c|c|c|c|c|}
\hline Variabel & & Olahan & is Gulung & & \\
\hline Output, Input, Harga & $\begin{array}{l}\text { Noodle } \\
\text { sosgul }\end{array}$ & $\begin{array}{l}\text { Soya } \\
\text { Sosgul }\end{array}$ & $\begin{array}{l}\text { Cheesy } \\
\text { Sosgul }\end{array}$ & $\begin{array}{l}\text { Potato } \\
\text { Sosgul }\end{array}$ & $\begin{array}{l}\text { Spicy } \\
\text { Sosgul }\end{array}$ \\
\hline Output (buah/Bulan) & 42.791 & 4.918 & 6.689 & 3.361 & 6.618 \\
\hline Bahan Baku (buah/Bulan) & 42.791 & 4.918 & 6.689 & 3.361 & 6.618 \\
\hline Tenaga Kerja (HOK/Bulan) & 26,00 & 26,00 & 26,00 & 26,00 & 26,00 \\
\hline Faktor Konversi & 1,00 & 1,00 & 1,00 & 1,00 & 1,00 \\
\hline Koefisien Tenaga Kerja (HOK/buah) & 0,00 & 0,01 & 0,00 & 0,01 & 0,00 \\
\hline Harga Output $(\mathrm{Rp} / \mathrm{buah}$ & $4.000,00$ & $7.000,00$ & $8.000,00$ & $8.000,00$ & $6.000,00$ \\
\hline Upah Rata-rata Tenaga Kerja (Rp/HOK) & $46.153,85$ & $46.153,85$ & $46.153,85$ & $46.153,85$ & $46.153,85$ \\
\hline \multicolumn{6}{|l|}{ Pendapatan dan Keuntungan } \\
\hline Harga Bahan Baku (Rp/buah) & 750,00 & 750,00 & 750,00 & 750,00 & 750,00 \\
\hline Sumbangan Input Lain (Rp/buah) & 691,13 & $4.681,13$ & $3.685,06$ & $6.730,79$ & $3.818,91$ \\
\hline Nilai Output (Rp) & $4.000,00$ & $7.000,00$ & $8.000,00$ & $8.000,00$ & $6.000,00$ \\
\hline Nilai Tambah (Rp/buah) & $2.558,87$ & $1.568,87$ & $3.564,94$ & 519,21 & $1.431,09$ \\
\hline Rasio Nilai Tambah (\%) & 63,97 & 22,41 & 44,56 & 6,49 & 23,85 \\
\hline Imbalan Tenaga Kerja (Rp/Bulan) & 28,04 & 244,00 & 179,40 & 357,04 & 181,32 \\
\hline Bagian Tenaga Kerja (\%) & 1,10 & 15,55 & 5,03 & 68,76 & 12,67 \\
\hline Keuntungan (Rp/buah) & $2.530,83$ & $1.324,87$ & $3.385,54$ & 162,18 & $1.249,76$ \\
\hline Tingkat Keuntungan (\%) & 98,90 & 84,45 & 94,97 & 31,24 & 87,33 \\
\hline \multicolumn{6}{|l|}{ Balas Jasa untuk Faktor Produksi } \\
\hline Margin (Rp/buah) & $3.250,00$ & $6.250,00$ & $7.250,00$ & $7.250,00$ & $5.250,00$ \\
\hline Keuntungan $(\%)$ & 77,87 & 21,20 & 46,70 & 2,24 & 23,80 \\
\hline Tenaga Kerja $(\%)$ & 0,86 & 3,90 & 2,47 & 4,92 & 3,45 \\
\hline Input Lain $(\%)$ & 21,27 & 74,90 & 50,83 & 92,84 & 72,74 \\
\hline
\end{tabular}


Tabel 4. Harga pokok produksi dan Harga pokok penjualan (per buah) di CV Cucurutuku Ceria Bandar Lampung

\begin{tabular}{lrrrr}
\hline Varian & $\begin{array}{c}\text { HPP } \\
\text { produksi }\end{array}$ & $\begin{array}{c}\text { Biaya } \\
\text { non } \\
\text { produksi }\end{array}$ & $\begin{array}{c}\text { HPP } \\
\text { penjualan }\end{array}$ & Harga \\
\hline Noodle & 962,85 & 477,09 & $1.439,95$ & 4000 \\
Soya & $1.926,86$ & $3.253,65$ & $5.180,52$ & 7000 \\
Cheesy & $1.768,44$ & $2.448,19$ & $4.216,63$ & 8000 \\
Potato & $2.182,56$ & $4.725,25$ & $6.907,81$ & 8000 \\
Spicy & $1.982,22$ & $2.464,98$ & $4.447,20$ & 6000 \\
\hline
\end{tabular}

Nilai tambah terbesar dari lima varian sosis gulung adalah varian cheesy yaitu sebesar Rp3.564,94 per buah sedangkan nilai tambah terkecil adalah varian potato yaitu sebesar Rp519,21 per buah. Nilai tambah pada sosgul varian cheesy terbesar karena memiliki harga jual yang cukup tinggi tetapi memiliki sumbangan input yang kecil, sedangkan nilai tambah pada varian potato memiliki nilai tambah terkecil karena memiliki harga jual yang tinggi tetapi memiliki sumbangan input yang paling tinggi sehingga mempengaruhi nilai tambah pada varian tersebut. Keuntungan yang diperoleh dari hasil pengolahan sosis gulung terbesar yaitu varian sosgul cheesy sebesar Rp3.385,54 per buah karena memiliki nilai tambah yang tinggi tetapi nilai imbalan tenaga kerja yang kecil, sedangkan keuntungan terkecil adalah varian potato sosgul sebesar Rp162,18 per buah karena memiliki nilai tambah yang terkecil namun memiliki nilai imbalan tenaga kerja yang tinggi.

\section{Analisis Harga Pokok Produksi dan Harga Pokok Penjualan}

Harga pokok produksi dihitung menggunakan metode Variabel costing dapat dilihat pada Tabel 4 yang terbagi lima varian. Harga pokok produksi varian noodle sebesar Rp962,85 per buah, varian soya sebesar Rp1.926,86, varian cheesy sebesar Rp1.768,44, varian potato sebesar Rp2.182,56 dan varian spicy sebesar Rp1.982,22 per buah. Hasil penelitian ini sejalan dengan Hadi, Ismono dan Yanfika (2015) bahwa jika total biaya nonproduksi per buah yang dikeluarkan besar dan jumlah produksi yang dihasilkan besar, maka harga pokok produksi yang didapatkan menjadi lebih kecil

Harga pokok produksi terbesar terdapat pada varian potato sebesar Rp2.182,56 dengan biaya nonproduksi per buah sebesar Rp4.725,25, hal ini berpengaruh dengan harga jual yang tinggi juga terhadap varian tersebut dengan harga jual sebesar Rp8.000,00 per buah. Harga pokok produksi terkecil terdapat pada varian noodle sebesar Rp962,85 per buah dengan biaya nonproduksi per buah sebesar Rp477,09 sehingga berpengaruh dengan harga jual yang kecil terhadap varian tersebut dengan harga jual sebesar Rp4000,00 per buah.

Harga pokok penjualan terbesar terdapat pada varian potato sebesar Rp6.907,81 harga jual sebesar Rp8.000 sehingga keuntungan yang diperoleh sebesar Rp1.092,19 sedangkan harga pokok penjualan terkecil terdapat pada varian noodle sosgul sebesar Rp1.439,95 dengan harga jual sebesar Rp4.000 sehingga keuntungan yang diperoleh sebesar Rp2.560,05 per buah. Besar kecil biaya produksi maka berpengaruh terhadap keuntungan yang diperoleh pada perusahaan tersebut.

\section{KESIMPULAN}

Nilai tambah terbesar pada varian cheesy sosgul sebesar Rp3.564,94 sedangkan nilai tambah terendah adalah varian potato sosgul sebesar Rp519,21. Harga pokok produksi varian noodle sebesar Rp962,85 per buah, varian soya sebesar Rp1.926,86 per buah, varian cheesy sebesar Rp1.768,44 per buah, varian potato sebesar Rp2.182,56 per buah dan varian spicy sebesar Rp1.982,22 per buah. Harga pokok penjualan varian noodle sebesar Rp1.439,95 per buah, varian soya sebesar Rp5.180,52 per buah, varian cheesy Rp4.216,63 per buah, varian potato sebesar Rp6.907,81 per buah, dan untuk varian spicy sebesar Rp4.447,20 per buah. Semua varian sosis gulung memberikan keuntungan yang berbedabeda bagi perusahaan dan layak untuk diusahakan.

\section{DAFTAR PUSTAKA}

Ayu BW, Ismono RH dan Soelaiman A. 2013. Analisis nilai tambah pada klaster industri pengolahan ikan teri kering di Pulau Pasaran Kota Bandar Lampung. Jurnal Ilmu Ilmu Agribisnis: $\quad 1 \quad$ (3):246-253. https://jurnal.fp.unila.ac.id/index.php/JIA/art icle/view/580/542. [4 Januari 2020].

Dinas Perkebunan dan Peternakan Provinsi Lampung. 2018. Produksi Daging Ayam di Provinsi Lampung tahun 2016- 2018. Dinas Perkebunan dan Peternakan Provinsi Lampung. Bandar Lampung.

Febriyanti F, Affandi MI dan Kalsum U. 2017. Analisis nilai finansial dan nilai tambah agroindustri keripik pisang skala umk di Kota Metro. Jurnal Ilmu Ilmu Agribisnis: 5 (1):48- 
Jurnal Ilmu Ilmu Agribisnis: Journal of Agribusiness Science, 9(4), November 2021

56.

https://jurnal.fp.unila.ac.id/index.php/JIA/artic le/view/1674/1500. [12 Maret 2020].

Hadi AF, Ismono RH dan Yanfika H. 2015. Analisis harga pokok produksi, laba usaha, dan permintaan ayam ras pedaging probiotik di Kota Metro. Jurnal Ilmu Ilmu Agirbisnis: 3 (3):235-242.

https://jurnal.fp.unila.ac.id/index.php/JIA/artic le/view/1047/952. [15 Januari 2020].

Hayami. 1987. Agricultural Marketing And Processing In Up Land Java : A Perspective frome A Sunda Village. The CGPRT Centre. Bogor.

Laisa DD, Sayekti WD dan Nugraha A. 2013. Analisis harga pokok produksi dan strategi pengembangan industri pengolahan ikan teri nasi kering di Pulau Pasaran Teluk Betung
Barat Bandar Lampung. Jurnal Ilmu Ilmu Agribisnis:

1

(2):111-117. http://jurnal.fp.unila.ac.id/index.php/JIA/articl e/viewFile/237/236. [15 Januari 2020].

Mulyadi. 2002. Sistem Akuntansi. Salemba Empat. Jakarta.

2005. Akuntansi Biaya. Unit Penerbitan dan Percetakan Sekolah Tinggi Ilmu Manajemen YKPN Universitas Gajah Mada. Yogyakarta.

Mumpuningsih G. 2008. Analisis nilai tambah dan penerimaan agroindustri tiwul instant di Malang Selatan. Jurnal Penelitian Pertanian Tropika: 18(2):88-98. [15 Januari 2020].

Swastha B dan Irawan. 2005. Asas-asas Marketing. Liberty. Yogyakarta.

Windiani dan Ari. 2014. Variasi Resep Praktis Untuk Menu Ayam Goreng. Fmedia. ISBN:9790065221. Jakarta. 